\title{
Jolanta Tambor, Oberschlesien - Sprache und Identität, OLMS, Hildesheim-Zürich-New York 2011, ss. 285
}

Recenzowana tutaj praca Jolanty Tambor jest w przeważającej części niemieckim tłumaczeniem jej wcześniejszej książki - cieszącej się wielką poczytnością monografii Mowa Górnoślązaków oraz ich świadomość językowa i etniczna, wydanej pierwszy raz w Katowicach w roku 2006 i wznowionej już w roku 2008. Jej recenzję ogłosiłem w szóstym roczniku „Studiów Językoznawczych” [Walczak 2007: 198-2002]. Ponieważ jednak recenzowana praca, przeznaczona głównie dla odbiorcy niemieckiego, jest w stosunku do poprzedniej w dużej mierze przeredagowana i uzupełniona, nie będzie od rzeczy przypomnieć zmodyfikowaną i zrelatywizowaną do wersji niemieckojęzycznej ocenę tej fundamentalnej monografii śląskoznawczej.

Książka sytuuje się w obszarze dialektologii polskiej, wydatnie jednak poszerzonym o rozległą i wyjątkowo złożoną problematykę świadomości językowej i etnicznej użytkowników „mowy górnośląskiej”. W dużym stopniu o walorach i wynikach publikacji decyduje ,rdzenna śląskość” Autorki. Warto tu przypomnieć doskonale znany dialektologom fakt, że najlepsze opisy gwar wyszły spod pióra autochtonów, czego dowodem są prace Stanisława Dobrzyckiego, Edwarda Klicha, Adama Tomaszewskiego, Stanisława Bąka, Augustyna Steffera, Bernarda Sychty, Piotra Bąka, Mieczysława Szymczaka, Władysława Brzezińskiego, Mariana Kucały, Henryka Nowaka, Honoraty Skoczylas, Józefa Kąsia itd. Autorce rozprawy, wykraczającej znacznie poza dialektologiczny opis gwary, bardzo przydała się też znajomość - z autopsji i uczestnictwa śląskiej kultury i najnowszych dziejów Śląska. Jest bowiem faktem, co z naciskiem podkreśla Antonina Kłoskowska, że badacz będący zarazem uczestnikiem badanej kultury jest w stanie opisywać ją bardziej kompetentnie. 
Monografia Jolanty Tambor zawiera analizę i opis świadomości językowej i etnicznej (czy narodowej) rdzennych mieszkańców Górnego Śląska na tle czynników politycznych, społecznych, demograficznych, gospodarczych i kulturalnych, które ją ukształtowały. Ponadto Autorka zamieściła w książce opis mowy Górnego Śląska na przełomie XX i XXI wieku, przy czym skonfrontowała, co bardzo ważne i interesujące, faktyczny stan uzusu językowego i świadomość językową użytkowników mowy śląskiej. Publikację dopełnia utrzymana w paradygmacie naukowym kognitywizmu, operująca wypracowanym przez kognitywizm instrumentarium badawczym prezentacja wizerunku (prototypu, stereotypu i autostereotypu) Ślązaka w przeszłości i dziś. Całość odznacza się wielostronnością ujęcia i oglądu, skrupulatnością opisu i analizy, trafnością interpretacji, ostrożnością w wyciąganiu wniosków i formułowaniu tez. Słowem, jest to praca wręcz wzorcowa, przykład znakomitego warsztatu naukowego i perfekcjonistycznej postawy badawczej.

W moim przekonaniu do najważniejszych walorów książki należą:

A. Bardzo obszerny (ok. 60 godz. nagrań spontanicznych rozmów i ok. 40 godz. nagrań tekstów folklorystycznych, wyniki ankiet i wywiadów kwestionariuszowych, książki i artykuły z wywiadami, opowiadaniami, gadkami, rozmaite notki prasowe, popularne słowniki gwary górnośląskiej itd.) i bardzo interesujący materiał językowy, w całości zebrany przez Autorkę i przez nią wprowadzony do obiegu naukowego. Rzecz jasna, wartość materiałową monografii wydatnie podnosi dołączona do niej płyta z nagraniami autentycznych, spontanicznych rozmów Ślązaków.

B. Wyjątkowo udane połączenie klasycznej dialektologii, dążącej w gruncie rzeczy do zrekonstruowania idealnego modelu gwary (charakteryzującego się pełnym zestawem i maksymalną frekwencją tekstową właściwych dla niej cech) i socjolingwistyki, zmierzającej do uchwycenia rzeczywistego obrazu uzusu gwarowego, uwarunkowanego czynnikami w szerokim tego słowa znaczeniu społecznymi. Harmonijne i owocne połączenie tych różnych przecież punktów widzenia nie jest sprawą prostą, toteż nie zdarza się często. Monografia Jolanty Tambor może i w tym względzie służyć za wzór.

C. Rozległe kompetencje teoretyczno-metodologiczne Autorki, która gruntownie opanowała podstawy teoretyczne i metodologię różnych paradygmatów lingwistycznych i różnych subdyscyplin językoznawstwa i zależnie od rozpatrywanej problematyki z powodzeniem stosuje aparat pojęciowo-terminologiczny i instrumentarium badawcze dialektologii, socjolingwistyki, pragmalingwistyki oraz semantyki kognitywnej z jej fundamentalnymi konstruktami w postaci prototypu i stereotypu. 
D. Ważne i interesujące wyniki naukowe, z których wspomnimy tutaj tylko o jednym: Autorka przekonująco dowiodła, że mowa aglomeracji miejskiej Górnośląskiego Okręgu Przemysłowego w swoich zasadniczych rysach i właściwościach nie jest czymś jakościowo różnym od (śląskich) gwar wiejskich, które klasyczna dialektologia - co najwyraźniej artykułował Karol Dejna - skłonna jest uznawać za wyłączny przedmiot swoich badań. Swoistość sytuacji miast aglomeracji górnośląskiej, w których gwara od początku towarzyszyła procesom urbanizacji i które odznaczają się niskim stopniem wykształcenia i tradycjonalizmem zawodowym swoich mieszkańców, powoduje, że podobnie jak gwary wiejskie, miejska gwara („mowa”) górnośląska zachowuje charakter ludowy.

Monografia Jolanty Tambor adresowana jest nie tylko do językoznawców, lecz także do socjologów, politologów i kulturoznawców, w szczególności zainteresowanych problematyką śląską i /lub osobiście (własną biografią, więzami rodzinnymi itd.) związanych z Górnym Śląskiem. Ten szeroki adres czytelniczy tłumaczy fenomen (gdyż w wypadku pracy stricte naukowej jest to niewątpliwy fenomen) rychłego drugiego wydania. Sądzę, że przenikający monografię ciepły i serdeczny stosunek do ziemi i ludzi stanowi dla czytelników dodatkową, i to podwójną, gwarancję wiarygodności stwierdzeń i tez Autorki - podwójną, gdyż, po pierwsze, wynikającą z tego, że Jolanta Tabor pisze o czymś, co zna osobiście i co sama przeżyła, a po drugie, uzasadnioną jej cechami jako Ślązaczki, a więc osoby „robotnej”, solidnej i skrupulatnej.

Jak wspomniałem na wstępie, recenzowana książka stanowi w przeważającej części przekład (przeredagowany i uzupełniony) wcześniejszej, polskojęzycznej wersji monografii. Nie brak jednak też zasadniczych różnic między wcześniejszą wersją polską a późniejszą niemiecką. Różnice te dokumentują rozwój i postęp teoretycznej refleksji Autorki w kwestii statusu „mowy” śląskiej. Najbardziej zewnętrzną oznaką tego rozwoju jest rezygnacja w wersji niemieckojęzycznej z terminu ,gwara” - zamiast niego pojawia się termin najbardziej ,naukowy”, pozwalający na uniknięcie dylematu ,język czy dialekt”, a mianowicie termin „etnolekt”, a ponadto takie określenia, jak „mowa”, a nawet ,język" (co już sugeruje odrębność socjolingwistyczną, a nawet postulowaną odrębność w obszarze językoznawstwa zewnętrznego). Z perspektywy polimetologicznej oznacza to abstrahowanie od pewnych uwarunkowań historycznych etnolektu śląskiego.

Książka w moim przekonaniu swoim adresem czytelniczym wykracza poza dość hermetyczne środowisko silezjologów. Jeszcze raz na koniec należałoby 
podkreślić i uwypuklić jej wymiar teoretyczny. Trzeba stwierdzić, że oprócz opisu świadomości językowej i etnicznej Górnoślązaków oraz prototypu, stereotypu i autostereotypu Górnoślązaka pojawia się tu obszerna część (napisana specjalnie z myślą o wersji niemieckojęzycznej), w której w centrum uwagi Badaczki staje status etnolektu śląskiego, rozpatrywany głównie w kontekście problematyki tożsamościowej, polityki językowej i uwarunkowań prawnych (Europejska karta języków mniejszościowych lub regionalnych, polska Ustawa o mniejszościach narodowych i etnicznych oraz o języku regionalnym), a także na szerszym tle europejskich i pozaeuropejskich etnolektów mniejszościowych. Rozpatrując te kwestie, nawet czytelnik polski musi sięgnąć do wersji niemieckojęzycznej.

Bogdan Walczak

\section{Bibliografia}

Tambor Jolanta (2011), Oberschlesien - Sprache und Identität, OLMS, HildesheimZürich-New York.

Walczak Bogdan (2007), J. Tambor, Mowa Górnoślązaków oraz ich świadomość językowa i etniczna, „Studia Językoznawcze”, t. 6, s. 198-202. 